\title{
Öğretmenlerin Çokkültürlü Eğitime Yönelik Tutumları: Van İli Örneği*
}

\author{
Mecit ASLAN1, İshak KOZİKOĞLU²
}

${ }^{1}$ Yrd. Doç. Dr., Yüzüncü Yu Üniversitesi, maslan4773@gmail.com

${ }^{2}$ Arş. Gör. Dr., Yüzüncü Yul Üniversitesi, ishakkozikoglu@,hotmail.com

Geliş Tarihi/Received: 05.03.2017～Kabul Tarihi/Accepted: 22.08.2017

e-Yayım/e-Printed: 30.10 .2017

DOI: http://dx.doi.org/10.14582/DUZGEF.1829

ÖZ

$\mathrm{Bu}$ araştırmanın amacı, Van ilindeki ilkokul, ortaokul ve liselerde görev yapan öğretmenlerin çokkültürlü eğitime yönelik tutumlarını incelemektir. Tarama modelindeki bu araştırma Van ilindeki ilkokul, ortaokul ve liselerde görev yapmakta olan 201 öğretmen ile yürütülmüştür. Çalışmanın verileri Yazıcı, Başol ve Toprak (2009) tarafından Türkçe’ye uyarlanan "Öğretmelerin Çokkültürlü Tutum Ölçeği (ÖÇTÖ)" ile toplanmıştır. Elde edilen verilerin analizinde betimsel istatistikler, bağımsız gruplar t-testi, Kruskall Wallis-H testi ve ANOVA kullanılmıştır. Araştırma sonucunda öğretmenlerin çokkültürlü eğitime yönelik olumlu tutuma sahip oldukları, erkek öğretmenlerin kadın öğretmenlere göre, branşı sosyal bilimler olan öğretmenlerin diğer öğretmenlere göre ve iki dilli öğretmenlerin tek dilli öğretmenlere göre daha olumlu tutuma sahip oldukları ortaya çıkmıştır.

Anahtar Kelimeler: Kültür, Çokkültürlülük, Çokkültürlü eğitim

\section{Teachers' Attitudes Toward Multicultural Education: Sample of Van}

\begin{abstract}
The aim of this research is to analyze attitudes of the teachers working in primary, secondary and high schools in Van towards multicultural education. The research was conducted with 201 teachers in Van. Data of the research was collected by "Teacher Multicultural Education Survey (TMAS)" adapted by Yazıcı, Başol \& Toprak (2009). Descriptive statistics, independent samples t-test, Kruskall Wallis-H test and ANOVA were used in the analysis of the data collected. As a result of the research, it was found that teachers have positive attitude towards multicultural education. In addition, it was found that male teachers have more positive attitudes than female teachers, social science teachers have more positive attitudes than other teachers and bilingual teachers have more positive attitudes than monolingual teachers.
\end{abstract}

Keywords: culture, multiculturalism, multicultural education

\section{GİRIŞ̧}

Kültür sosyologlar, antropologlar, eğitimciler gibi farklı kesimlerin çok uzun yıllardır üzerine konuştuğu, araştırma yaptı̆̆ bir kavram olarak ortaya çıkmaktadır. Yapılan çalışmalar sonucunda kültürün ne olduğu ve sınırları ile ilgili farklı tanımlar ve görüşler ortaya konmuştur. Kültürün ne olduğuna ilişkin çoğu tanımı ve görüşü kapsayacak bir ifadeyle Varış (1994) kültürü "bir yaşam biçimi” olarak ifade etmektedir. Çünkü kültür yeme-içme, giyim-kuşam, iletişim şekli, değer sistemi vb. pek çok unsurun yaşama yansımasıdır (Göçer, 2012). Kültür, toplumsal ilişkileri belirlemekte ve ondan etkilenmektedir. Farklı kültürlere sahip bireylerin sanat eserleri, aile hayatları, evlenme biçimleri, değerleri, normları vs. de farklı olmaktadır (Başeymez, 2009). Küreselleşen dünyada bir toplum içerisinde sadece tek bir kültürün bulunması neredeyse imkânsız hale gelmiş ve farklı kültürler aynı çatı altında kendilerine yer edinmişlerdir. Bu durum toplumdaki kültürel çeşitliliği veya bir diğer ifadeyle çokkültürlü bir toplum yapısını beraberinde getirmiştir.

Çokkültürlülük farklı din, dil, ırka sahip farklı kültürdeki yani farklı etnik \kültürel kökene sahip toplulukların bir arada yaşama projesidir. Etnik ve dini grupların yoğunlaştığı ülkelerdeki kültürel çeşitlilikler çokkültürlülük olarak adlandırılmaktadır. Çokkültürlülük post-modern dönemde meydana gelen bir olgudur ve çıkışı itibariyle post-modern dönemin çeşitlilik, çoğulculuk gibi özelliklerinde temellenmektedir (Yakışır, 2009).

\footnotetext{
* Bu çalışma, 23-24 Kasım 2015 tarihinde Yüzüncü Yıl Üniversitesinde düzenlenen Bütün Yönleriyle Öğretmen Sempozyumu'nda sözlü bildiri olarak sunulmuştur.
} 
Kültürel çeşitlilik toplumdaki bireylerin birçok kültüre maruz kalması durumudur. Toplumdaki bireyler kültürel çeşitliliği kabul ederek zenginleşir ve birbirleriyle uyum içerisinde çalışabilirler (Gretta, 2001).

Dünyadaki her ülke kendi sınırları içindeki çeşitli gruplar arasında etnik rekabet, düşmanlık ve çatışmayı en aza indirmeye çalışır. Her ülke etnik kökeni, ırkı, dili, dini inancı ne olursa olsun tüm vatandaşların ortak insanlık, ihtiyaçlar, umutlar ve korkuları paylaştığı ulusa bağlı kalmasını sağlamak için çalışır (Hinton, 2011). Bu noktada eğitim kurumlarına önemli görevler düştüğü ifade edilebilir. Çünkü kültür ile yakından ilişkili olan eğitim kültürden etkilenir ve kültür tarafından şekillendirilir. Ayrıca, eğitim kültürün aktarılması ve korunması için de güçlü bir araç görevi görmektedir (Gretta, 2001). Dolayısıyla, toplumdaki kültürel çeşitliliğin eğitim sürecinde yer alması ve eğitimin bu çokkültürlü yapıya uygun olarak yapılması gerekliliği düşüncesi çokkültürlü eğitim kavramını da beraberinde getirmiştir.

Çokkültürlü eğitim, cinsiyet, sosyal sınıf, etnik, ırksal ve kültürel özellikleri fark etmeksizin tüm öğrencilerin öğrenmeleri için okulda eşit fırsatların sağlanması gerektiği fikrini savunan bir eğitim anlayışıdır (Banks \& Banks, 2010). Çokkültürlü eğitim farklılıklara ulaşma, eşitliği, karş1lıklı hoşgörüyü ve saygıyı teşvik etme, tüm öğrencilerin kapasitelerinin en üst seviyelerine ulaşmalarını sağlama, vatandaşları çeşitlilik içeren bir topluma hazırlama ve daha iyi bir dünya yaratma gibi amaçlara hizmet etmektedir (Levinson, 2007). Bu eğitim anlayışında her kültürün önemli görülmesi gerekmektedir. Öğrenciler kendi kültürlerinin bilgi kaynaklarını değerlendirebilir, kültürel deneyimlerini sınıfın geri kalanıyla paylaşabilir, kendi kültürleri ile ilgili yazılar yazabilir ve araştırmalar yapabilirler (Gretta, 2001). Çokkültürlü bir eğitim ortamının oluşturulabilmesi için öğretim programlarının bu anlayışa uygun olarak geliştirilmesi, bütün öğrencilerin kültürel farklılıklarının kabul edilmesi ve değer görmesi, öğrencilerin yaşantılarından örnekler sunması, öğrenciler arasında sosyal etkileşimlerin yaratılması ve bireysel farklılıkların dikkate alınarak farklı öğretim yöntem ve tekniklerinin kullanılması gerekmektedir (Başbay \& Bektaş, 2009).

Çokkültürlü eğitimin tanımına ve amaçlarına bakıldığında çokkültürlü eğitimin öğrenci odaklı olduğu görülmektedir. Çokkültürlü eğitim öğrenciye dayalı bir eğitim olduğundan amacı ve verilecek eğitimin niteliği ülkeden ülkeye farklılık gösterebilmektedir. Her ülkenin çokkültürlü eğitim için amaçladıkları ve içeriği kendi ülkesinin özelliklerine göre şekillenmektedir. Ayrıca, her ülkenin çokkültürlü eğitim konusundaki duyarll1ık noktaları da farklıdır (Polat, 2009). Dolayısıyla, tüm çokkültürlü toplumlar için geçerli olan bir yaklaşımın veya modelin varlığından bahsetmek mümkün olmamaktadır.

Her ne kadar çokkültürlü eğitim günümüz toplumlarında kaçınılmaz bir fenomen olarak karşımıza çıksa da bu konudaki tartışmalar ve eleştiriler de devam etmektedir. Başbay ve Bektaş (2009) çokkültürlü eğitime karşı olanların genellikle bu eğitim anlayışının toplumların bütünleşmesi noktasında zedeleyici olduğunu düşündüklerini belirtmektedir. Kanada ve Avustralya gibi çokkültürlü eğitimi resmi olarak kabul etmiş ülkelerde bile bu konudaki tartışmalar devam etmektedir. Her ne kadar bu konuda ilkesel bir uzlaşma sağlanmış olsa da, pratikte işin nasıl olacağı önemli ve bünyesinde çeşitli sorunlar barındıran bir konudur (Toprak, 2008). Dolayısıyla, mümkün olan en az sorunla karşılaşmak için bu konuda benimsenecek politikalarda ve yapılacak eğitim çalışmalarında geçerli ve güvenilir bilimsel araştırma sonuçlarının temel alınması önemli olmaktadır.

Yurtdışında uzun bir geçmişe ve zengin bir literatüre sahip olan çokkültürlü eğitimin ülkemizde ise son yıllarda çalışılmaya başlandığı görülmektedir. Son yıllarda yapılan araştırmalarda çokkültürlü eğitime yönelik ölçek geliştirme çalışmalarının yapıldığı (Yazıcı, Başol \& Toprak, 2009; Yavuz \& Anıl, 2010; Başbay \& Kağnıcı, 2011; Polat, 2012), kuramsal olarak çokkültürlü eğitimin ve yurtdışındaki uygulamaların ele aldığı (Cırık, 2008; Aydın, 2013; Kaya \& Adın, 2014), farklı derslerde veya programlarda çokkültürlü eğitimin nasıl uygulandığ1 veya uygulanabileceği konusunun ele alındığı (Altaş, 2003; Açıkalın, 2010; Keskin \& Yaman, 2014) ve öğretim elemanlarının, öğretmen adaylarının ve okul yöneticilerinin çokkültürlülüğe ve çokkültürlü eğitime ilişkin görüşleri, algıları, farkındalıklanı, yeterlikleri veya tutumlarının belirlenmesine dönük çalışmaların yapıldığ (Çoban, Karaman \& Doğan, 2010; Başarır, 2012; Coşkun, 2012; Demir, 2012; Karaçam \& Canan, 2012; Polat, 2012; Başbay, Kağnıcı \& Sarsar, 2013; Çekin, 2013; Koç-Damgacı \& Aydın, 2013; Demir \& Başarır, 2013; Polat \& Kılıç, 2013; Ünlü \& Örten, 2013; Aydın \& Tonbuloğlu, 2014; Başbay, 2014; Tortop, 2014) 
görülmektedir. Bununla birlikte, öğretmenler üzerinde yapılan çalışmaların yeterli düzeyde olmadığ1 görülmektedir. Dolayısıyla, eğitim programlarının uygulayıcısı olan öğretmenlerin çokkültürlü eğitime yönelik görüşlerinin, algılarının, yeterliklerinin ve tutumlarının farklı çalışmalarla ortaya konulması önemli bir çalısma alanı olarak araştırmacıların önünde durmaktadır.

\subsection{Amaç}

Bu çalışmanın amacı Van ilindeki ilkokul, ortaokul ve liselerde görev yapan öğretmenlerin çokkültürlü eğitime yönelik tutumlarını incelemektir. Bu genel amaç doğrultusunda aşağıdaki sorulara yanıt aranmıştır:

1. Van ilindeki ilkokul, ortaokul ve liselerde görev yapan öğretmenlerin çokkültürlü eğitime yönelik tutumları nasıldır?

2. Van ilindeki ilkokul, ortaokul ve lise öğretmenlerinin çokkültürlü eğitime yönelik tutumları,
a. Cinsiyete,
b. Branşa,
c. Mesleki kıdeme,
d. Okul kademesine ve
e. Tek dilli veya çok dilli olma durumuna göre değişmekte midir?

\section{YÖNTEM}

\subsection{Araştırmanın Modeli}

Öğretmenlerin çokkültürlü eğitime yönelik tutumlarının incelendiği bu çalışmada tarama modeli kullanılmıştır. Geçmişte veya halen var olan bir durumu betimlemesi açısından tarama modeli çalışmanın amacina uygun bir modeldir (Karasar, 2012, s. 77).

\section{2. Çalışma Grubu}

Betimsel tarama modelindeki bu çalışma Van ilindeki ilkokul, ortaokul ve liselerde görev yapmakta olan 201 öğretmen ile yürütülmüştür.

Tablo1. Çalışma grubunda yer alan öğretmenlerin demografik değişkenlere göre dağılımı

\begin{tabular}{|c|c|c|c|}
\hline \multicolumn{2}{|l|}{ Demografik Değişken } & Sayı (S) & Yüzde (\%) \\
\hline \multirow{2}{*}{ Cinsiyet } & Kadin & 101 & 50.2 \\
\hline & Erkek & 100 & 49.8 \\
\hline \multirow{4}{*}{ Mesleki Kıdem } & $1-3 Y_{11}$ & 120 & 59.7 \\
\hline & 4-6 Yil & 34 & 16.9 \\
\hline & 7-9 Yil & 27 & 13.4 \\
\hline & 10 Y1l ve üzeri & 20 & 10.0 \\
\hline \multirow{10}{*}{ Branş / Alan } & Temel Ĕğitim & 29 & 14.4 \\
\hline & Türk Dili & 30 & 14.9 \\
\hline & Fen Bilimleri & 26 & 12.9 \\
\hline & Sosyal Bilimler & 20 & 10.0 \\
\hline & Yabancı Dil & 25 & 12.4 \\
\hline & Matematik & 25 & 12.4 \\
\hline & Din Kültürü & 10 & 5.0 \\
\hline & Özel Yetenek & 15 & 7.5 \\
\hline & Rehberlik/Özel Eğitim & 11 & 5.5 \\
\hline & Mesleki ve Teknik Eğitim & 10 & 5.0 \\
\hline \multirow{2}{*}{$\begin{array}{l}\text { Tek dilli/İki dilli } \\
\text { olma durumu }\end{array}$} & Tek dilli & 119 & 59.2 \\
\hline & İki dilli & 82 & 40.8 \\
\hline \multirow{3}{*}{ Okul kademesi } & İlkokul & 34 & 16.9 \\
\hline & Ortaokul & 92 & 45.8 \\
\hline & Lise & 75 & 37.3 \\
\hline
\end{tabular}

Tablo 1'de görüldüğü gibi, çalışma grubunda yer alan öğretmenlerin 101’i kadın ve 100’ü erkektir. Öğretmenlerinin 120’si “1-3 Yll”, 34’ü “4-6 Yil”, 27’si “7-9 Yil” ve 20’si “10 Y1l ve üzeri” mesleki k1deme sahiptir. Öğretmenlerin 119’u tek dilli iken, 82'si iki dilli; 34'ü ilkokulda, 92'si ortaokulda ve 75’i lisede görev yapmaktadır. Çalışma grubunda yer alan öğretmenlerin branşa/alana göre dağılımları ise şöyledir: Temel Eğitim ( $n=29)$, Türk Dili ( $n=30$ ), Fen Bilimleri ( $n=26)$, Sosyal Bilimler ( $n=20)$, Yabanc1 Dil ( $n=25)$, Matematik ( $n=25)$, Din Kültürü ( $n=10)$, Özel Yetenek ( $n=15)$, Rehberlik/Özel Eğitim ( $n=11)$, Mesleki ve Teknik Eğitim $(n=10)$.

\subsection{Veri Toplama Arac1}

Araştırmada veri toplama aracı olarak Ponterotto, Baluch, Greig, ve Rivera (1998) tarafindan geliştiren ve Yazıc1, Başol ve Toprak (2009) tarafindan Türkçe’ye uyarlanan “Öğretmelerin Çokkültürlü Tutum Ölçeği 
(ÖÇTÖ)" kullanılmıştır. Beşli likert türündeki ölçek 7'si olumsuz ve 13'ü olumlu olmak üzere toplam 20 maddeden oluşmaktadır. Ölçeğin iç tutarlık kat sayısı uyarlama çalışmasında .74, bu çalışmada .72 olarak tespit edilmiştir.

\subsection{Verilerin Analizi}

Elde edilen verilerin analizinde SPSS paket programı kullanılmıştır. Öğretmelerin Çokkültürlü Tutum Ölçeğinin maddelerine ilişkin görüşlerini belirlemek için aritmetik ortalama ve standart sapma değerlerine; öğretmenlerin tutumlarının cinsiyet ve tek dilli/çok dilli olma durumu değişkenlerine göre değişip değişmediğini belirlemek için bağımsız gruplar t-testi; branş değişkenine göre değişip değişmediğini belirlemek için Kruskall Wallis-H testi; mesleki kıdem ve okul kademesi değişkenine göre değissip değişmediğini belirlemek için ANOVA kullanılmıştır. ANOVA sonucunda anlamlı fark çıkması durumunda bu farkın hangi gruplardan kaynaklandığını belirlemek için post-hoc testlerinden LSD ve Bonferroni kullanılmıştır. Çalışmada tüm analizler için anlamlılık düzeyi $\mathrm{p}<.05$ olarak kabul edilmiştir.

\section{BULGULAR}

$\mathrm{Bu}$ bölümde öğretmenlerin çokkültürlü eğitime yönelik tutumlarına ilişkin bulgulara yer verilmiştir. Öncelikle, ölçeğe ve maddelere ilişkin ortalama ve standart sapma değerlerine yer verilmiştir. Bunun devamında öğretmenlerin tutumlarının demografik değişkenlere göre değişip değişmedini gösteren fark analizlerine yer verilmiştir.

Tablo 2. Öğretmenlerin ölçeğinin maddelerine ve toplamına verdikleri puanlara ilişkin ortalama ve standart sapma değerleri $(\mathrm{N}=201)$

\begin{tabular}{|c|c|c|}
\hline Maddeler & $\overline{\mathbf{X}}$ & SS \\
\hline 1. Kültürel olarak farklı öğrenci grubuna öğretmenlik yapmayı önemli buluyorum. & 4.57 & .66 \\
\hline $\begin{array}{l}\text { 2. Öğretim yöntemleri, kültürel olarak farklı öğrenci gruplarının ihtiyaçlarını karşılayacak şekilde } \\
\text { uyarlanmalıdır. }\end{array}$ & 4.70 & .56 \\
\hline $\begin{array}{l}\text { *3. Bazen öğretmenlerin çokkültürlülük bilinci ve eğitimi konusuna çok fazla vurgu yapıldığını } \\
\text { düşünüyorum. }\end{array}$ & 2.97 & .96 \\
\hline 4. Öğretmenler, öğrencilerinin kültürel geçmişlerinin farkında olma sorumluluğuna sahiptirler. & 3.72 & 1.12 \\
\hline 5. Öğrencileri kültürel olarak daha iyi tanımak için aile bireyleriyle sık sık görüşürüm. & 3.43 & .99 \\
\hline $\begin{array}{l}\text { *6. Kişinin kendi kültürü içinde yapıp ettikleriyle gururlanmasını teşvik etmek öğretmenin } \\
\text { sorumlulukları arasında değildir. }\end{array}$ & 2.70 & 1.31 \\
\hline 7. Sınıf kültürel olarak farklılaştıkça öğretmenin işi daha da zorlaşır. & 3.60 & 1.33 \\
\hline $\begin{array}{l}\text { 8. Kültürel olarak farklı geçmişe sahip öğrencilerin ihtiyaçlarına hitap etmesi için, öğretmenin } \\
\text { rolünün yeniden tanımlanması gerektiğine inanıyorum. }\end{array}$ & 3.96 & .98 \\
\hline $\begin{array}{l}\text { 9. İki dilli (ana dili farklı olan) çocuklarla ilgilenirken, iletişim stilleri sık sık davranış problemi olarak } \\
\text { yorumlanır. }\end{array}$ & 3.47 & 1.15 \\
\hline 10. Sınıf kültürel olarak farklılaştıkça öğretmenin işi daha değerli olur. & 4.04 & 1.07 \\
\hline 11. Kültürel olarak farklı geçmişe sahip öğrencilerden çok şey öğrenebilirim. & 4.42 & .76 \\
\hline *12. Öğretmenlerin çokkültürlülük eğitimi almaları gerekli değildir. & 1.95 & 1.06 \\
\hline 13. Etkili bir öğretmen olmak için sınıfta var olan kültürel farklılıkların bilincinde olmak gerekir. & 4.62 & .61 \\
\hline $\begin{array}{l}\text { 14. Çokkültürlülük bilincine ilişkin eğitim kültürel açıdan farklı öğrenci topluluğu ile daha etkili } \\
\text { çalısmama yardım edebilir. }\end{array}$ & 4.18 & .79 \\
\hline *15. Öğrenciler sadece Türkçe iletişim kurmayı öğrenmelidirler. & 1.95 & 1.22 \\
\hline *16. Günümüz müfredatı çokkültürcülüğe ve farklılığa aşırı önem vermektedir. & 2.12 & 1.02 \\
\hline 17. Sınıfımdaki kültürel geçmiş farklılığının bilincindeyim. & 4.18 & .72 \\
\hline 18. Sınıfımın yapısı ne olursa olsun, öğrencilerin çokkültürlü farklılığın bilincinde olmaları önemlidir. & 4.32 & .71 \\
\hline *19. Çokkültürlülüğ̈̈n bilincinde olmak öğrettiğim konularla ilgili değildir. & 2.60 & 1.32 \\
\hline *20. Öğrencilere kültürel farklılı̆̆1 öğretmek sadece sınıfta çatışma yaratır. & 1.58 & .86 \\
\hline TOPLAM & 3.97 & .39 \\
\hline
\end{tabular}

Not: (*) şeklinde işaretlenen maddeler olumsuz maddelerdir.

Tablo 2'de görüldüğü üzere, öğretmenlerin çokkültürlü eğitime yönelik tutumlarının ortalaması X= 3.97 (Olumsuz maddeler ters kodlandıktan sonra bu değer elde edilmiştir) olarak saptanmıştır. Ölçek maddeleri içerisinde öğretmenlerin en olumlu tutuma sahip oldukları maddeler "M2- Öğretim yöntemleri, kültürel olarak, farkh ögrenci gruplarmın ibtiyaçlarm karşılayacak, şekilde uyarlanmahder." (X= 4.70), "M13- Etkili bir ögretmen olmak için simfta var olan kültürel farklllkklarn bilincinde olmak gerekir." (X=4.62) ve "M1- Kültürel olarak farkl ögrenci grubuna ögretmenlik yapmayı önemli buluyorum.” (X= 4.57) olmuştur. Öğretmenlerin en olumsuz tutuma sahip oldukları maddeler ise, "M20- Öğrencilere kültürel farklilĭg ögretmek sadece simfta çatıs̆ma yaratır." (X= 1.58), “M12Öğretmenlerin çokkültürlülük eğitimi almalar gerekli değildir." (X=1.95) ve "M15- Öğrenciler sadece Türkşe iletişim kurmayı ögrenmelidirler.” $(\mathrm{X}=1.95)$ şeklindedir. 
Tablo 3. Öğretmenlerin çokkültürlü eğitime yönelik tutumlarının cinsiyet değişkeni açısından aritmetik ortalama, standart sapma ve t-testi sonuçları

\begin{tabular}{|c|c|c|c|c|c|c|}
\hline Cinsiyet & $\mathbf{n}$ & $\overline{\mathbf{x}}$ & $\boldsymbol{S S}$ & $t$ & $S d$ & $p$ \\
\hline Kadın & 101 & 77.71 & 8.62 & -3.014 & 199 & .003 \\
\hline Erkek & 100 & 80.98 & 6.59 & & & \\
\hline
\end{tabular}

Tablo 3'te görüldüğü üzere, öğretmenlerin çokkültürlü eğitime yönelik tutumları cinsiyet değişkenine göre istatistiksel olarak anlamlı fark göstermektedir $[\mathrm{p}<.05]$. Kadın ve erkeklerin tutumlarının aritmetik ortalamaları incelendiğinde bu farklılığın erkek öğretmenler lehine olduğu görülmektedir.

Tablo 3. Öğretmenlerin çokkültürlü eğitime yönelik tutumlarının branş değişkenine göre farklılaşıp farklılaşmadığını belirlemek üzere yapılan non-parametrik Kruskal Wallis-H testi sonuçları

\begin{tabular}{|c|c|c|c|c|c|c|}
\hline Branş & $\mathbf{N}$ & Sira Ort. & Sd & $\boldsymbol{X}^{2}$ & $\mathrm{p}$ & Anlamli Fark \\
\hline 1.Temel Eğitim & 29 & 116.60 & \multirow{13}{*}{9} & \multirow{13}{*}{37.04} & \multirow{13}{*}{.000} & \multirow{13}{*}{$\begin{array}{l}1-3,2-3,4-3,9-3,1-5, \\
2-5,4-5,9-5,1-6,2-6, \\
4-6,8-6,9-6,1-10,2- \\
10,4-10,9-10,\end{array}$} \\
\hline 2.Türk Dili & 30 & 125.82 & & & & \\
\hline 3.Fen Bilimleri & 26 & 82.87 & & & & \\
\hline 4.Sosyal Bilimler & 20 & 125.05 & & & & \\
\hline 5.Yabanc1 Dil & 25 & 86.82 & & & & \\
\hline 6.Matematik & 25 & 61.76 & & & & \\
\hline 7.Din Kültürü & 10 & 92.45 & & & & \\
\hline 8.Özel Yetenek & 15 & 105.17 & & & & \\
\hline 9.Rehberlik/Özel & 11 & 146.45 & & & & \\
\hline Eğitim & & & & & & \\
\hline 10.Mesleki ve & 10 & 66.20 & & & & \\
\hline Teknik Eğitim & & & & & & \\
\hline Toplam & 201 & & & & & \\
\hline
\end{tabular}

Tablo 4’te öğretmenlerin çokkültürlü eğitime yönelik tutumları branş/öğretmenlik alanı değişkenine göre incelendiğinde, en olumlu tutuma sahip alanların Rehberlik/Özel Ë̆itim, Türk Dili, Sosyal Bilimler ve Temel Eğitim alanları olduğu; en olumsuz tutuma sahip alanların ise Matematik, Mesleki ve Teknik Eğitim ile Fen Bilimleri alanları olduğu görülmektedir. Ayrıca, gerçekleştirilen non-parametrik Kruskal Wallis-H testi sonucunda öğretmenlerin çokkültürlü eğitime yönelik tutumlarının branş/alan değişkenine göre istatistiksel olarak da anlamlı fark gösterdiği ortaya çıkmıştır [p<.05]. Daha sonra belirlenen anlamlı farklılı̆̆n hangi gruplardan kaynaklandığını belirlemek üzere ikili karşılaştırmalar için Mann Whitney-U testine başvurulmuştur. Gerçekleştirilen analiz sonucunda genel olarak Fen, Matematik ve Mesleki/Teknik Eğitim alanlarının Temel Eğitim, Türk Dili, Sosyal Bilimler ve Rehberlik/Özel Eğitim alanlarından istatistiksel olarak anlamlı bir farklılık gösterdiği saptanmıştır $[\mathrm{p}<.05]$. Bu fark sözel/sosyal bilimler lehinedir.

Tablo 5. Öğretmenlerin çokkültürlü eğitime yönelik tutumlarının mesleki kıdem değişkeni açısından aritmetik ortalama, standart sapma ve ANOVA sonuçları

\begin{tabular}{|c|c|c|c|c|c|c|c|c|c|c|}
\hline \multicolumn{4}{|c|}{ Betimsel İstatistikler } & \multicolumn{5}{|c|}{ ANOVA Sonuçlant } & \multicolumn{2}{|c|}{ Post Hoc (LSD) } \\
\hline $\begin{array}{l}\text { Mesleki } \\
\text { Kidem }\end{array}$ & $\mathbf{n}$ & $\mathbf{X}$ & SS & Var. K. & K.T. & Sd & K.O. & $\mathbf{F}$ & $\mathrm{p}$ & $\begin{array}{l}\text { Anlamlı } \\
\text { Fark }\end{array}$ \\
\hline 1. $1-3 \mathrm{Y} 1 \mathrm{l}$ & 120 & 77.98 & 7.68 & G. Aras1 & 570.99 & 3 & 190.33 & 3.200 & .024 & $1-2,1-4$ \\
\hline 2. $4-6$ Yil & 34 & 81.21 & 7.05 & G. İçi & 11715.99 & 197 & 59.47 & & & \\
\hline 3. $7-9$ Yil & 27 & 80.96 & 7.56 & Toplam & 12286.99 & 200 & & & & \\
\hline $\begin{array}{ll}\text { 4. } & 10 \text { Yil ve } \\
& \text { Üzeri }\end{array}$ & 20 & 82.15 & 9.11 & & & & & & & \\
\hline Toplam & 201 & 79.34 & 7.84 & & & & & & & \\
\hline
\end{tabular}

Tablo 5’te öğretmenlerin çokkültürlü eğitime yönelik tutumları mesleki kıdem değişkenine göre incelendiğinde, genel olarak mesleki kıdemi yüksek olan öğretmenlerin daha olumlu tutuma sahip olduğu görülmektedir. Ayrıca, gerçekleştirilen varyans analizi sonucunda öğretmenlerin çokkültürlü eğitime yönelik tutumlarının mesleki kıdem değişkenine göre istatistiksel olarak da anlamlı fark gösterdiği ortaya çıkmıştır $[\mathrm{p}<.05]$. ANOVA sonrası belirlenen anlamlı farklıı̆ın hangi gruplardan kaynaklandığını belirlemek üzere tamamlayıcı post-hoc analiz tekniklerine geçilmiştir. Gerçekleştirilen LSD testi sonucunda "1-3 Yıl” mesleki kıdeme sahip öğretmenlerin tutumlarının "4-6 Yil” ve "10 Yil ve Üzeri” mesleki kıdeme sahip öğretmenlerin tutumlarından istatistiksel olarak anlamlı bir farklılık gösterdiği saptanmıştır [p<.05]. 
Tablo 6. Öğretmenlerin çokkültürlü eğitime yönelik tutumlarının okul kademesi değişkeni açısından aritmetik ortalama, standart sapma ve ANOVA sonuçları

\begin{tabular}{|c|c|c|c|c|c|c|c|c|c|c|}
\hline \multicolumn{4}{|c|}{ Betimsel İstatistikler } & \multicolumn{6}{|c|}{ ANOVA Sonuçlar1 } & \multirow{2}{*}{$\begin{array}{l}\text { Post Hoc } \\
\text { Anlamli Fark }\end{array}$} \\
\hline Okul kademesi & $n$ & $\boldsymbol{X}$ & $S S$ & Var. K. & K.T. & Sd & K.O. & $\mathbf{F}$ & $\mathrm{p}$ & \\
\hline İlkokul & 34 & 81.71 & 6.97 & G. Aras1 & 231.44 & 2 & 115.72 & 1.901 & .152 & \\
\hline Ortaokul & 92 & 78.96 & 8.65 & G. İçi & 12055.55 & 198 & 60.89 & & & \\
\hline Lise & 75 & 78.73 & 7.01 & Toplam & 12286.99 & 200 & & & & \\
\hline Toplam & 201 & 79.34 & 7.84 & & & & & & & \\
\hline
\end{tabular}

Tablo 6'da görüldüğü üzere, öğretmenlerin çokkültürlü eğitime yönelik tutumları görev yapmakta oldukları okul kademesi değişkenine göre istatistiksel olarak anlamlı fark göstermemektedir [p>.05]. Bu bulgulardan hareketle, hangi okul kademesinde çalışıyor olursa olsun öğretmenlerin çokkültürlü eğitime yönelik benzer tutumlara sahip oldukları söylenebilir.

Tablo 7. Öğretmenlerin çokkültürlü eğitime yönelik tutumlarının tek dilli/iki dilli olma değișkeni açısından aritmetik ortalama, standart sapma ve t-testi sonuçları

\begin{tabular}{lrrrrrr}
\hline Tek dilli/İki Dilli & $\mathbf{n}$ & $\overline{\mathbf{X}}$ & $\boldsymbol{S S}$ & $\boldsymbol{t}$ & $\boldsymbol{S d}$ & $\boldsymbol{P}$ \\
\hline Tek dilli & 119 & 76.81 & 7.69 & -5.976 & 199 & .000 \\
\hline İki dilli & 82 & 83.01 & 6.51 & & & \\
\hline
\end{tabular}

Tablo 7'de görüldüğü üzere, öğretmenlerin çokkültürlü eğitime yönelik tutumları tek dilli veya iki dilli olma değişkenine göre istatistiksel olarak anlamlı fark göstermektedir $[\mathrm{p}<.05]$. Her iki grubun tutumlarının aritmetik ortalamaları incelendiğinde bu farklıllğın iki dilli olan öğretmenler lehine olduğu görülmektedir.

\section{TARTIŞMA ve SONUÇ}

Çokkültürlü eğitim günümüz eğitim sistemlerinde üzerine konuşulan, tartışlan, savunulan ve bir o kadar da eleştirilen bir kavram olarak karşımıza çıkmaktadır. Bu eğitim anlayışını resmi olarak benimseyen ülkeler olduğu gibi, tamamen karşı çıkan ülkeler de bulunmaktadır. Türkiye'de ise bu kavramın batıya nazaran sonradan ele alındığı, çalışmalar yapılmaya başlandığı ve tartışmaların devam ettiği söylenebilir. Van ilindeki ilkokul, ortaokul ve lise öğretmenlerinin çokkültürlü eğitime yönelik tutumlarının incelendiği bu araştırmada öğretmenlerin olumlu bir tutuma sahip oldukları ortaya çıkmıştır. Bu sonuç kültürel çeşitlilik ve çokkültürlü eğitim ile ilgili öğretmen adayları ve öğretmenlerle gerçekleştirilen çalışmaların (Başarır, 2012; Bulut \& Başbay, 2015; Çoban, Karaman \& Doğan, 2010; Sevinç, Titrek \& Önder, 2009; Tortop, 2014) sonuçlarılyla tutarlık göstermektedir. Bu çalışmalarda katılımcıların genel olarak kültürel farklılıklara ve çokkültürlü eğitime yönelik olumlu tutuma sahip oldukları ve eğitim ortamında farklı kültürlere yer verilmesi gerektiği inancını taşıdıkları görülmüştür. Van ili özelinde düşünüldügünde ise, eğitim ortamının farklı kültürleri barındırma ihtimali ve öğretmenin bazı kültürel özelliklerinin öğrencilerden farklı olması burada görev yapan öğretmenlerin çokkültürlü eğitim konusunda farkındalık geliştirmelerinde etkili olmuş olabilir. Öğretmen ve öğretmen adaylarıyla yapılan çalışmaların yanı sıra, Damgacı \& Aydın (2013) tarafindan yapılan çalışmada öğretim elemanlarının çokkültürlü eğitime yönelik olumlu tutuma sahip oldukları ortaya çıkmıştır. Bununla birlikte, Yazıc1, Başol \& Toprak (2009) öğretmenlerin çokkültürlü eğitim ile ilgili olum tutumları ve farkındalıkları olmasına rağmen bazı sınıf öğretmenlerinin bu konuda yeterli bilinçte olmadıkları sonucuna ulaşmıştır.

Öğretmenlerin tutumları cinsiyet değişkeni açısından ele alındığında erkek öğretmenlerin kadın öğretmenlere göre daha olumlu bir tutuma sahip olduğu ortaya çıkmıştır. Çokkültürlü eğitimin geleneksel eğitim anlayışına alternatif olarak ortaya çıkan bir eleştirel pedagoji olduğu (Aydın, 2013) düşünüldügünde, dezavantajlı grup konumundaki kadınların değişimi daha çok savunması beklenmekle birlikte, Aslan \& Kozikoğlu (2015) tarafından yapılan eleştirel pedagoji konusundaki araştırma sonucu ile tutarlık göstermektedir. Bu çalışma da erkek öğretmen adaylarının eleştirel pedagojiye ilişkin görüşlerinin kadınlara göre daha olumlu olduğu belirlenmiştir. Toplumsal cinsiyet rolleri kültürler arasında, bir toplumdaki farklı zamanlarda ve aynı toplumdaki farklı mikro kültürlerde farklılık gösterebilmektedir (Banks \& Banks, 2010). Türkiye gibi ataerkil bir gelenekten gelen toplumlarda hakimiyet ve değiştirme iradesi erkeklerin elinde bulunmaktadır. Böylesi bir sistemde kuralları erkek belirler. Kadınlar ise bu sistemde var olabilmek için belirlenen kuralları benimsemek ve bu doğrultuda hareket etmek durumunda kalırlar (Demren, 2001). 
Dolayısıyla, her ne kadar zaman zaman tersi sonuçlar ortaya çıksa da, kadınların geleneği ve geleneksel yaklaşımları sürdürme eğilimleri içinde yaşadıkları toplum düşünüldüğünde anlaşılır bir durum olabilmektedir. Nitel verilerle de desteklenen benzer çalışmaların farklı bölgelerdeki örneklem grupları üzerinde yapılması, kadın ve erkekler arasındaki görüş farklılıklarını ve nedenlerini belirleme noktasında daha net veriler sağlayabilir.

Öğretim programları kültürlerarası bir perspektif geliştirmek için çeşitli firsatlar sunmaktadır. Farklı branşlarda yapılabilecek çeşitli uygulamalar ile bu perspektifin geliştirilmesi mümkün olmaktadır (NCCA \& Tormey, 2005). Branş/alan değişkenine göre öğretmenlerin tutumları ele alındığında Rehberlik/Özel Eğitim, Türk Dili, Sosyal Bilimler ve Temel Eğitim alanlarının çokkültürlü eğitime yönelik daha olumlu tutuma sahip oldukları ortaya çıkmıştır. Ayrıca, bu alanların Matematik alanından anlamlı düzeyde farklılaştığı ortaya çıkmıştır. Bu sonuç sosyal alanlarda öğretmenlik yapanların fen ve matematik alanlarına göre daha olumlu tutuma sahip olduklarını göstermektedir. Bu durum sosyal alanlarda görev yapan öğretmenlerin çokkültürlü eğitimi derslerinde daha fazla kullandığı veya kullanabileceği gerçeği ile açıklanabilir. Benzer şekilde Yazıcı, Başol \& Toprak (2009) tarfindan yapılan çalışmada öğretmenlerin çokkültürlü eğitime yönelik tutumlarının branşlarına göre farklılık gösterdiği görülmektedir. Polat (2009) tarafından yapılan çalışmada öğretmen adaylarının çokkültürlü kişilik özelliklerinin bölüm değişkenine göre farkllık gösterdiği, Tortop (2014) tarafindan yapılan çalışmada ise farklı bölümlerde öğrenim gören öğretmen adaylarının çokkültürlü eğitime yönelik benzer bir tutuma sahip oldukları ortaya çıkmıştır.

Mesleki kıdem açısından ele alındığında, genel olarak mesleki kıdemi yüksek olan öğretmenlerin çokkültürlü eğitime yönelik daha olumlu tutuma sahip oldukları sonucu ortaya çıkmıştır. Mesleki kıdemi yüksek olan öğretmenlerin eğitim ortamında kültürel çeşitlilik ile daha fazla karşılaştığı ve bu konuda bir anlayış geliştirdiği söylenebilir. Bununla birlikte literatürde bu sonuca ters düşen araştırmalara (Bulut \& Başbay, 2015; Polat, 2012; Yazıcı, Başol \& Toprak, 2009) da rastlanmaktadır. Bulut \& Başbay (2015) kıdemi fazla olan öğretmenlerin çokkültürlülüğe ilişkin farkındalık düzeylerinin düşük olmasını mesleki tükenmişlik ile açıklamışlardır. Görev yaptıkları okul kademesine göre öğretmenlerin çokkültürlü eğitime yönelik benzer tutumlar geliştirdikleri ortaya çıkmıştır. Bir başka ifadeyle öğretmenler hangi okul kademesinde çalışıor olurlarsa olsunlar çokkültürlü eğitime yönelik olumlu bir tutuma sahiptirler. Bu durum öğretmenlerin görev yaptığ1 bütün okul kademelerinin benzer bir öğrenci profiline sahip olmaları ve dolayısıyla öğretmenlerin bu duruma benzer tepkiler göstermeleri ile açıklanabilir.

Tek dilli veya iki dilli olma durumuna göre ele alındıklarında, iki dilli öğretmenlerin çokkültürlü eğitim konusunda daha olumlu tutuma sahip oldukları sonucuna ulaşılmıştır. Bu durum iki dilli öğretmenlerin kendilerinin çokkültürlü bir kişilik yapısı sergilemesi ile açıklanabilir. Çünkü dil en önemli ve bir toplumu diğerlerinden ayıran birinci kültür unsuru (Bulut \& Orhan, 2012) ve kültürün sonraki nesillere aktarılmasında en etkili unsurdur (Göçer, 2012). Gerek yazılı gerek sözlü kültür unsurları dil aracıllğıyla sonraki nesillere aktarılmaktadır. Öğrenilen her dil ile birlikte farklı bir kültürün özellikleri, yaşam biçimleri ve kendine özgü özellikleri de öğrenilmiş olmaktadır (Göçer, 2012). Dolayısıyla, iki dilli bireyler aynı zamanda iki farklı kültürü bilen ve hayatında uygulayan bireyler olarak görülebilir. Bu durum da onların çokkültürlü eğitime yönelik daha olumlu tutum geliştirmesini sağlamıştır.

Çalışmanın sınırlıkları dikkate alındığında, benzer çalışmaların farklı sosyo-ekonomik ve kültürel özellikler gösteren bölgelerde yapılması, nitel ve karma araştırma yöntemleri kullanılarak araştırmaların desenlenmesi ve öğretmen dışındaki diğer eğitim paydaşlarıyla da çalışmların yürütülmesi önerilebilir. Her ne kadar bu çalısmada öğretmenlerin çokkültürlü eğitime yönelik olumlu bir tutuma sahip oldukları belirlenmiş olsa da, düşük kıdeme sahip veya tek dilli öğretmenlerin diğer öğretmelere göre daha olumsuz tutuma sahip olduklar1 düşünüldüğünde, hizmet öncesi ve hizmet içi öğretmen eğitimleriyle çokkültürlülük konusunda eğitim geçmişi ve yaşantısı daha az olan öğretmenlerin bu konudaki farkındalıkları ve yeterlikleri arttırılabilir. 


\section{KAYNAKÇA}

Açıkalın, M. (2010). Sosyal bilgiler eğitiminde yeni yaklaşımlar: Çokkültürlü ve küresel eğitim. İlkögretim Online, 9(3), 1226-1237.

Altaş, N. (2003). Çokkültürlü din eğitimi modeli geliştirmede işlem basamakları için bir deneme. Değerler Eğitimi Dergisi, 1(1), 19-42.

Aslan, M., \& Kozikoğlu, İ. (2015). Pedagojik Formasyon Eğitimi Alan Öğretmen Adaylarının Eleştirel Pedagojiye İlişkin Görüşleri. Abant İzet Baysal Üniversitesi Ë̆gitim Fakültesi Dergisi, 15(1), 1-14.

Aydın, H. (2013). Dünyada ve Türkiye' de çokkültürlü eğitim tartısmalar ve uygulamalar. Nobel Akademik Yayıncıllk.

Aydın, H., \& Tonbuloğlu, B. (2014). Graduate students perceptions' on multicultural education: A qualitative case study. Eurasian Journal of Educational Research, 57, 29-50.

Banks, J. A., \& Banks, C. A. M. (2010). Multicultural education: Issues and perspectives (Seventh edition). USA: Wiley.

Başarır, F. (2012). Öğretmen adaylarmm çok kültürlü eğitime ilişkin görüslerinin ve öz-yeterlik algılarmmn değerlendirilmesi (Erciyes Üniversitesi Örnĕgi). (Yayınlanmamış yüksek lisans tezi). Erciyes Üniversitesi, Kayseri.

Başbay, A. (2014). Investigation of multicultural education courses: The case of Georgia State University. Educational Sciences: Theory \& Practice, 14(2), 602-608.

Başbay, A., \& Bektaş, Y. (2010). Çokkültürlülük bağlamında öğretim ortamı ve öğretmen yeterlikleri. Ĕğtim ve Bilim, 34(152), 30-43.

Başbay, A., \& Kağnıcı, D. Y. (2011). Çokkültürlü yeterlik algıları ölçeği: Bir ölçek geliştirme çalışması. Education \& Science/Egitim ve Bilim, 36(161), 199-212.

Başbay, A., Kağnıc1, D. Y., \& Sarsar, F. (2013). Eğitim fakültelerinde görev yapmakta olan öğretim elemanlarının çokkültürlü yeterlik alg1larının incelenmesi. Turkish Studies, 8(3), 47-60.

Başeymez, F. (2009). Cokkeültürlülük açısından Hatay; sosyolojik bir yaklaşım. (Yayınlanmamış yüksek lisans tezi). Selçuk Üniversitesi, Konya.

Bulut, C., \& Başbay, A. (2015). Öğretmenlerin çok kültürlü yeterlik algılarının incelenmesi. Kastamonu Ĕ̆gitim Dergisi, 23(3), 957-978.

Bulut, M., \& Orhan, S. (2012). Türkçe-Edebiyat ders kitaplarının dil ve kültür aktarımındaki rolü ve önemi üzerine bir inceleme. The Journal of Academic Social Science Studies, 5(8), 297-311.

Cirık, İ. (2008). Çok kültürlü eğitim ve yansımaları. Hacettepe Üniversitesi Eğitim Fakültesi Dergisi, 34(34), 27-40.

Çekin, A. (2013). Çokkültürlülük ve din öğretimi: din kültürü ve ahlak bilgisi öğretmenlerinin çokkültürlü eğitime ilişkin tutumları çerçevesinde bir analiz. Electronic Turkish Studies, 8(12), 241-248.

Çoban, A. E., Karaman, N. G., \& Doğan, T. (2010). Öğretmen adaylarının kültürel farklılıklara yönelik bakış açılarının çeşitli demografik değişkenlere göre incelenmesi. Abant İz̨et Baysal Üniversitesi Eüitim Fakültesi Dergisi, 10(1), 125-131.

Coşkun, M. K. (2012). Din kültürü ve ahlak bilgisi öğretmen adaylarının çok kültürlü eğitime yönelik tutumları (İlahiyat-Eğitim DKAB karş1laştırmas1). Dumlupınar Üniversitesi Sosyal Bilimler Dergisi, 34, 33-44.

Damgacı, F. K., \& Aydın, H. (2013). Akademisyenlerin çokkültürlü eğitime ilişkin tutumları. Elektronik Sosyal Bilimler Dergisi, 45(45), 325-341.

Demir, S. (2012). Çok kültürlü eğitimin Erciyes Üniversitesi öğretim elemanları için önem derecesi. Electronic Turkish Studies, 7(4), 1453-1475.

Demir, S., \& Başarır, F. (2013). Çok kültürlü eğitim çerçevesinde öğretmen adaylarının öz-yeterlik algılarının incelenmesi. International Journal of Social Science, 6(1), 609-641.

Demren, Ç. (2001). Erkeklik, ataerkillik ve iktidar iliskileri. Ataerklik ve erkeklik biçimlerinin karşllkl iliskileri ve etkileşimleri. (Yayınlanmamış yüksek lisans tezi). Hacettepe Üniversitesi, Ankara.

Gretta, K. N. (2001). A critical analysis of multicultural education with special referance to the values issue in the South African context. (Yayınlanmamıs yüksek lisans tezi). Güney Afrika Üniversitesi, Eğitim Fakültesi.

Göçer, A. (2012). Dil-kültür ilişkisi ve etkileşimi üzerine. Türk Dili, 729, 50-57.

Hinton, S. (2011). Ethnic diversity, national unity and multicultural education in China. US-China Education Review B, 1(5), 726-739.

Karaçam, M. S.., \& Koca, C. (2012). Beden eğitimi öğretmen adaylarının çokkültürlülük farkındalıkları. Spor Bilimleri Dergisi: Hacettepe Üniversitesi, 23(3), 89-103.

Karasar, N. (2012). Bilimsel araştırma yöntemi: kavramlar, ilkeler, teknikeler. Ankara: Nobel Yayın Dağıtım.

Kaya, I., \& Aydın, H. (2014). Çŏ̆ulculuk, çokkültürlü ve çokdilli eğitim. Ankara: Anı Yayınc1lı.

Kaya, Y. (2014). Öğretmen adaylarının çokkültürlü eğitim hakkındaki bilgi, farkındalık ve yeterliliklerinin belirlenmesi. E-AJI (Asian Journal of Instruction), 2(1), 102-115.

Keskin, Y., \& Yaman, E. (2014). A new paradigm included in the elementary education social studies curriculum and course books: Multicultural education. TURKISH STUDIES-International Periodical for the Languages, Literature and History of Turkish or Turkic-, ISSN, 1308-2140. 
Koç-Damgacı, F., \& Aydın, H. (2013). Akademisyenlerin çokkültürlü eğitime ilişkin tutumları. Elektronik Sosyal Bilimler Dergisi, 12(45), 325-341.

Levinson, M. ( 2007). Common schools and multicultural education. Journal of Philosophy of Education, 41(4), 625-642.

National Council for Curriculum and Assessment (Ireland), \& Tormey, R. (2005). Intercultural education in the primary school. National Council for Curriculum and Assessment.

Polat, S. (2009). Öğretmen adaylarının çok kültürlü eğitime yönelik kişilik özellikleri. Inerntional Online Journal of Education Sciences, 1(1), 154-164.

Polat, S. (2012). Okul müdürlerinin çok kültürlülüğe ilişkin tutumlar1. Hacettepe Üniversitesi Eŭitim Fakültesi Dergisi, 42(42), 334-343.

Polat, İ., \& Kllıç, E. (2013). Türkiye'de çokkültürlü eğitim ve çokkültürlü eğitimde öğretmen yeterlilikleri. Yü̈züncü Yl Üniversitesi Ë̆itim Fakültesi Dergisi, 10(1),352-372.

Sevinç, V., Titrek, O., \& Önder, İ. (2009). Cok kültürlü eğitime ilişkin ögretmen adaylarnmn görüşleri. The International Symposium on Multi-Culturalism in Education, Isparta.

Tortop, H. S. (2014). Öğretmen adaylarının üstün yetenekli ve çok kültürlü eğitime ilișkin tutumları. Üstün Yetenekliler Ë̈itimi Arastrmalar Dergisi-Journal of Gifted Education Research, 2(2), 16-26.

Ünlü, İ., \& Örten, H. (2013). Öğretmen adaylarının çokkültürlülük ve çokkültürlü eğitime yönelik algılarının incelenmesi. Dicle Üniversitesi Ziya Gökalp Eğitim Fakültesi Dergisi, 21(2013), 287-302.

Varış, F. (1994). Ë̆itimde program geliştirme teori ve teknikleri. Ankara: Alkım Kitapçılık Yayıncıllk.

Yakıșır, A. N. (2009). Bir modern olgu olarak çokkültürlülïk. (Yayınlanmamış yüksek lisans tezi). Selçuk Üniversitesi, Konya.

Yavuz, G., \& Anıl, D. (2010). Öğretmen adayları için çok kültürlü eğitime yönelik tutum ölçeği: Güvenirlik ve geçerlik çalişması. International Conference on New Trends in Education and Their Implications. 11-13.

Yazıcı, S., Başol, G., \& Toprak, G. (2009). Öğretmenlerin çokkültürlü eğitim tutumları: Bir güvenirlik ve geçerlik çalışması. Hacettepe Üniversitesi Ë̆itim Fakültesi Dergisi, 37(37), 229-242.

\section{Citation Information}

Aslan, M. \& Kozikoğlu, İ. (2017). Öğretmenlerin Çokkültürlü Eğitime Yönelik Tutumları: Van İli Örneği. Dicle Üniversitesi Ziya Gökalp Eğitim Fakültesi Dergisi, 31, 729-737. 